\title{
Methylene Blue in the Treatment of Discogenic Low Back Pain
}

Gaurav Gupta, MD, FRCPC, Mohan Radhakrishna, MD, FRCPC, Jeffrey Chankowsky, MD, FRCPC, and Juan Francisco Asenjo, MD, FRCPC

From: McGill University Health Centre Pain Centre \& McGill University; Montreal, Quebec

Dr. Gupta is Adjunct Professor, Physical Medicine and Rehabilitation, McGill University Health Centre Pain Centre \& McGill University; , Montreal, Quebec. Dr. Radhakrishna is Assistant Professor, Physical Medicine and Rehabilitation, McGill University Health Centre Pain Centre \& McGill University; Montreal,

Quebec.

Dr. Chankowsky is Assistant Professor, Diagnostic Radiology \& Imaging, McGil University Health Centre \& McGill University, Montreal, Quebec.

Dr. Asenjo is Associate Professor, Anesthesia and Pain Management, McGill University Health Centre Pain Centre \& McGill University, Montreal Quebec

Address correspondence: Gaurav Gupta, MD, FRCPC The Alan Edwards Pain Management Unit, McGill University Health Centre Montreal General Hospital Campus 1650 Cedar Ave. Room E19 128 Montréal, Québec $\mathrm{H}_{3} \mathrm{G}_{1} \mathrm{~A}_{4}$

E-mail: gauravoogupta@gmail.com

Disclaimer: Dr. Gaurav Gupta received nonrestricted funding support provided by the Louise and Alan Edwards Foundation and Pfizer Canada for his fellowship training. Conflict of interest: None.

Manuscript received: Revised manuscript received: Accepted for publication:

Free full manuscript: www.painphysicianjournal.com
Background: The personal and societal impact of chronic low back pain is considerable. The intervertebral disc is considered the etiologic source in up to $40 \%$ of patients, with considerable previous efforts directed at developing reliable and efficacious treatments. Recent publications, including a double-blind, randomized, placebo-controlled trial, using a one-time treatment of methylene blue, showed statistically significant, clinically relevant improvements in pain and function in the treatment groups. The postulated mechanism of action of methylene blue is denervation of small nociceptive fibers that grow into the annulus fibrosis, which are implicated in discogenic pain.

Study Design: Retrospective case series.

Setting: Academic pain management center.

Objectives: To examine the outcomes for a cohort of patients treated with methylene blue for discogenic pain, discuss potential differences in selection and administration protocols and briefly review other proposed treatments for discogenic pain (e.g. intradiscal electrothermy therapy, intradiscal steroids, intradiscal biaccuplasty, rami communicans radiofrequency thermocoagulation, and chymopapain ).

Methods: This case series examines the pain and functional outcomes in 8 patients treated with a one-time administration of methylene blue for discogenic back pain. Follow-up information was available between 2 months and over one year, depending on the patient.

Results: Application of this treatment for these 8 patients for discogenic pain diagnosed by provocation discography showed only one clinical success at our center. Four patients had a time-limited clinical response in pain and/or function between 2 weeks and 5 months. Patient specific data are outlined in detail herein.

Conclusions: Low back pain ascribed to a discogenic source continues to be an elusive clinical entity to treat. We have reserved further treatment of methylene blue for discogenic pain until other controlled trials have been published.

\section{Limitations: A case series.}

Key Words: Low back pain, discogenic pain, provocation discography, methylene blue, spinal injections, intervertebral disc therapy, intradiscal therapy.

Pain Physician 2012; 15:333-338 he lifetime prevalence of low back pain (LBP) is approximately $70-90 \%$, and while it often resolves spontaneously, there is also a high rate of recurrence (1-3). Chronic pain can develop in up to
$10 \%$ of patients, leading to disability and high health care costs $(3,4)$. Low back pain, ascribed to internal disc disruption through provocation discography, has a reported prevalence of approximately $40 \%$, but 
there is an associated decline in prevalence with age (5). Over the years there have been many attempts at finding a safe, reproducible, and effective treatment for discogenic LBP (6).

Intradiscal methylene blue has been lauded as a potential "cure" for discogenic low back pain based on the results of two recent 2 trials $(7,8,9)$. The first, a prospective nonrandomized trial by Peng and colleagues (9), demonstrated the efficacy of a single administration of methylene blue dye in the treatment of discogenic low back pain. The second trial, a double blind, randomized control trial (DBRCT), demonstrated at the 2-year follow-up a statistical and clinically meaningful reduction in the mean numeric rating scale 101 (NRS101) pain score of 52.5 and Oswestry function score of 35.6. Furthermore, there was a reduction in medication usage and a $91 \%$ satisfaction rate (versus a $14 \%$ satisfaction rate in the control). A decrease in the NRS 101 of at least 20 points was seen in $89 \%$ of treated patients, of which $19 \%$ reported no further pain, and $28 \%$ reported dramatic improvements in symptoms (8).

Given the scientific rigor described, these results were extremely impressive and promising. We report here our experience with this treatment in a small cohort of patients, which did not conform to the results of Peng and colleagues $(8,9)$.

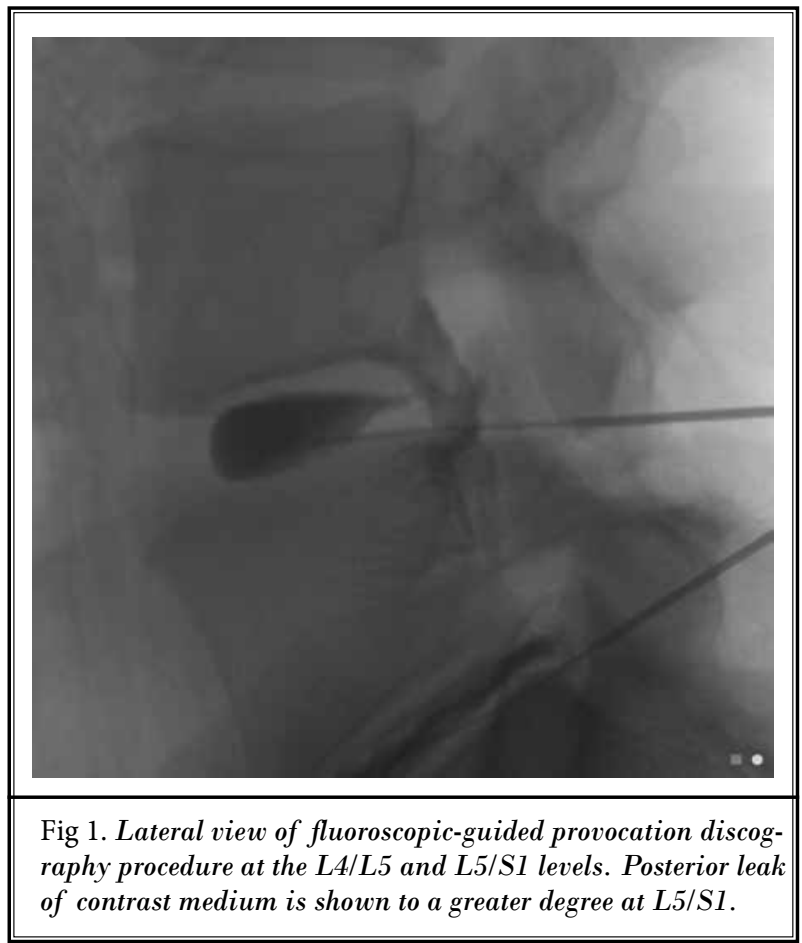

\section{Methods}

This is a retrospective case series of patients treated between 2010 and 2011 with methylene blue (MB) for suspected discogenic-based pain. Patients were selected for treatment based on a clinical evaluation and at the discretion of 2 treating clinicians (MR, JFA). Generally, selection was based on pain referral pattern, poor response to previous treatment, compatible imaging results, and a positive provocation discography (10). In contrast to the Peng et al study (8), patients with mental health issues and disc herniation were included in our study cohort. Care was taken to not to treat patients concurrently prescribed serotoninergic psychiatric medications to avoid any serious central nervous system reactions. We note any future elective administration of methylene blue should follow the current US Food and Drug administrations recommendations. These suggest stopping certain psychiatric medications (e.g SSRI, SNRI, TCA, MAOI, etc) for 2-5 weeks prior to treatment, depending on the medication, and then resuming these medications 24 hours after administration of methylene blue (11).

As shown in the lateral view in Fig. 1, provocation discography, using a double-needle technique, (i.e., needle through needle) and the standard posterolateral approach was performed under fluoroscopy in all patients by one of the 3 authors (MR, JC, JFA). Upon centering of the needle within the disc, nonionic contrast medium iohexol 240 was injected under low pressure. A positive/concordant response was defined if the patient experienced exact reproduction of his or her usual pain response pattern. Discograms were performed at a control level in all cases, except for patient \#5 who had reported concordant pain at all 3 levels tested. Treatment was applied for patient \#5 at the level with the worst pain. Into the concordant disc(s) one $\mathrm{mL}$ of $1 \% \mathrm{MB}$ was injected followed by one $\mathrm{mL}$ of $2 \%$ lidocaine. Unlike the previously described study, needles were not necessarily inserted in the patient's most painful side, and patients were discharged after 2 hours of lying supine postprocedure and computed tomography (CT) imaging (Figs. 2 and 3). As defined by Peng and colleagues (8), treatment success was defined as a sustained reduction in pain scores of at least $20 \%$ with a measurable/ definable improvement in function after a single injection of MB dye. 

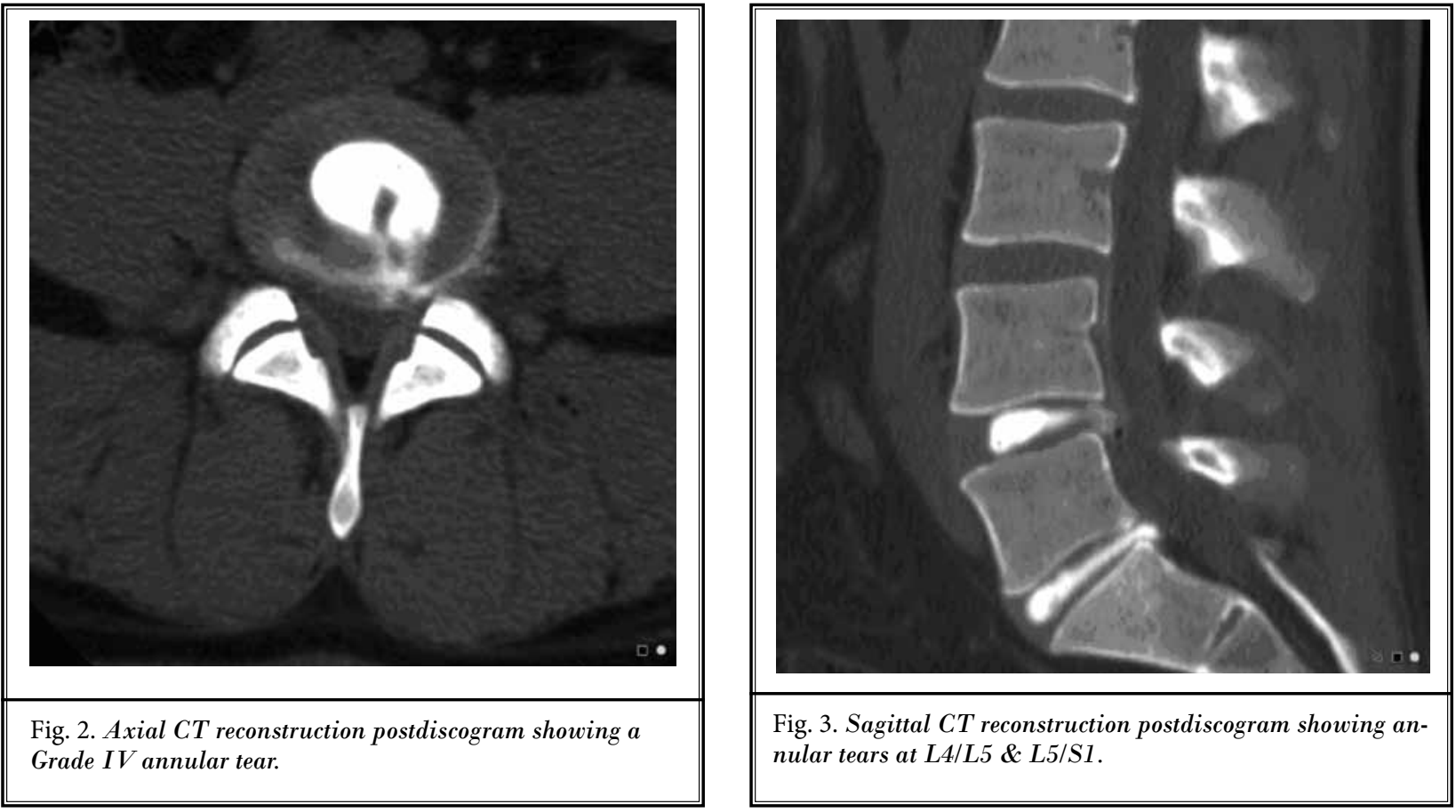

\section{Results}

Treatment was performed in 8 patients, with at least 2 months of follow-up data available that are summarized in Table 1.

Ages ranged between 36 to 77 years, with 5 women and 3 men. Pain duration varied from 1 to 7 years. All patients failed conservative treatment including physiotherapy, medication management; each had at least one interventional pain procedure prior to provocation discography.

Concordant response was achieved in all patients in at least one level. One patient (\#4) had treatment at 2 levels. Substantial annular tears (i.e., greater than Grade 3) on postdiscography CT scan were present in the discs injected with methylene blue in 7 patients $(8$ discs). Patient \#6 was treated at L4/L5, which showed a Grade 2 annular tear on postdiscography CT.

With the exception of patient \#2, who experienced a good, sustained clinical pain response with an associated improvement in function, treatment was otherwise not beneficial in our patient population. Three patients failed treatment outright (i.e., \#3, \#6 \& \#7). Patient \#1 had 5 months of relief with a recurrence thereafter. Patient \#4 had an $80 \%$ decrease in pain, but this subsided after 6 weeks. Patient \#5 reported a 30\% de-

crease in pain, but no change in function was achieved. Patient \#8 had complete relief, which diminished after 2 weeks. In our opinion, these cases represent a failure of treatment.

No adverse events were reported, but patient \#4 reported blue urine for one week, which could have an effect on the blinding of patients in clinical trials. Treatment was not repeated in any case.

\section{Discussion}

The postulated mechanism of methylene blue is denervation of small nociceptive fibers that grow into the annulus fibrosis, which are implicated in discogenic pain (8). Our case series revealed one clinical success in a cohort of 8 patients treated with a single injection of methylene blue for discogenic pain, which is contrary to the results reported by Peng and colleagues (8).

Peng and colleagues $(8,9)$ showed an $89 \%$ success rate in their DBRCT and $87 \%$ success rate in their cohort study. In comparison, our results revealed a success rate of only $13 \%$. The 5 months of $100 \%$ relief achieved by Patient \#1 was considered a failure because, unlike epidural treatment for radicular pain or medial branch thermo-radiofrequency for facet joint pain, there is 
Table 1. Patients treated with intradiscal methylene blue for presumed discogenic pain.

\begin{tabular}{|c|c|c|c|c|c|c|c|c|c|c|}
\hline \begin{tabular}{l|} 
Age/ \\
Gender
\end{tabular} & $\begin{array}{l}\text { Pain } \\
\text { Duration }\end{array}$ & $\begin{array}{l}\text { Previous } \\
\text { Treatment }\end{array}$ & $\begin{array}{l}\text { Pretreatment } \\
\text { MRI/CT }\end{array}$ & \begin{tabular}{|l|} 
Painful \\
Levels/ \\
Treated \\
Levels
\end{tabular} & $\begin{array}{l}\text { Post-CT } \\
\text { Discogram } \\
\text { Results }\end{array}$ & $\begin{array}{l}\text { Pain } \\
\text { Reduction } \\
\text { and } \\
\text { Duration }\end{array}$ & $\begin{array}{l}\text { Functional } \\
\text { Change }\end{array}$ & $\begin{array}{l}\text { Follow- } \\
\text { up } \\
\text { Time } \\
\text { Frame }\end{array}$ & $\begin{array}{l}\text { Adverse } \\
\text { Events }\end{array}$ & $\begin{array}{l}\text { Significant } \\
\text { Co- } \\
\text { morbidities }\end{array}$ \\
\hline$\# 1-66 \mathrm{~F}$ & 4 years & $\begin{array}{l}\text { Epidural, } \\
\text { SI, MBB }\end{array}$ & $\begin{array}{l}\text { AT-L4/L5 \& } \\
\text { L5/S1 }\end{array}$ & L5/S1 & $\begin{array}{l}\text { AT - L5/S1 } \\
\text { (Grade 4) }\end{array}$ & $\begin{array}{l}100 \% \text { x } 5 \\
\text { months }\end{array}$ & $\begin{array}{l}\text { Not } \\
\text { sustained }\end{array}$ & $>1$ year & None & $\begin{array}{l}\text { Diabetes, } \\
\text { hypothyroid, } \\
\text { dyslipidemia, } \\
\text { Raynaud's }\end{array}$ \\
\hline$\# 2-70 \mathrm{M}$ & 7 years & $\begin{array}{l}\text { Epidural, } \\
\text { TRF }\end{array}$ & $\begin{array}{l}\text { DB - L4/L5 } \\
\text { Z Joint OA } \\
\text { L5/S1 }\end{array}$ & L5/S1 & $\begin{array}{l}\text { AT - L4/ } \\
\text { L5 (Grade } \\
4) \& \text { L5/S1 } \\
\text { (Grade 4) }\end{array}$ & $\begin{array}{l}100 \% \\
\text { reduction } \\
\text { - ongoing }\end{array}$ & Good & One year & None & None \\
\hline$\# 3-77 \mathrm{~F}$ & 4 years & $\begin{array}{l}\text { SI, TRF, } \\
\text { Epidural, } \\
\text { VB (L2) }\end{array}$ & $\begin{array}{l}\text { CT Scan } \\
\text { - DDD \& } \\
\text { Z- Joint OA, } \\
\text { stable L2 }\end{array}$ & L5/S1 & $\begin{array}{l}\text { AT- L4/L5 } \\
\text { (Grade 4) } \\
\text { \& L5/ } \\
\text { S1(Grade 4) }\end{array}$ & None & None & $\begin{array}{l}>\text { One } \\
\text { year }\end{array}$ & None & $\begin{array}{l}\text { Depression, } \\
\text { osteoporosis, } \\
\text { hypertension } \\
\text { dyslipidemia }\end{array}$ \\
\hline$\# 4-44 \mathrm{M}$ & 4 years & Epidural & DH L4/L5 & $\begin{array}{l}\text { L4/L5 } \\
\text { L5/S1 }\end{array}$ & $\begin{array}{l}\text { AT - L3/ } \\
\text { L4 (Grade } \\
\text { 3) L4/L5 } \\
\text { (Grade 4) } \\
\text { \& L5/S1 } \\
\text { (Grade 4) }\end{array}$ & $\begin{array}{l}80 \% \text { x } 6 \\
\text { weeks }\end{array}$ & $\begin{array}{l}\text { Not } \\
\text { sustained }\end{array}$ & $>1$ year & $\begin{array}{l}\text { Blue } \\
\text { urine } \\
\text { for one } \\
\text { week }\end{array}$ & None \\
\hline$\# 5-46 \mathrm{~F}$ & 1 year & Epidural & $\begin{array}{l}\text { AT- L4/L5 \& } \\
\text { L5/S1 }\end{array}$ & L5/S1 & $\begin{array}{l}\text { AT- L3/ } \\
\text { L4 (Grade } \\
\text { 3) L4/L5 } \\
\text { (Grade 3) } \\
\text { \&L5/S1 } \\
\text { (Grade 4) }\end{array}$ & $30 \%$ & None & $\begin{array}{l}6 \\
\text { months }\end{array}$ & None & $\begin{array}{l}\text { Depression, } \\
\text { work-related } \\
\text { injury. }\end{array}$ \\
\hline$\# 6-36 \mathrm{M}$ & $>2$ years & $\begin{array}{l}\text { Epidural, } \\
\text { facet blocks }\end{array}$ & $\begin{array}{l}\text { AT- L2/L3 } \\
\text { DE-L4/L5 } \\
\text { DB-L5/S1 }\end{array}$ & L4/L5 & $\begin{array}{l}\text { AT- L4/L5 } \\
\text { (Grade 2) } \\
\text { \& L5/S1 } \\
\text { (Grade 4) }\end{array}$ & None & None & $\begin{array}{l}2 \\
\text { months }\end{array}$ & None & None \\
\hline$\# 7-58 \mathrm{~F}$ & 6 years & $\begin{array}{l}\text { Facet } \\
\text { blocks }\end{array}$ & $\begin{array}{l}\text { DB-L4/L5 } \\
\text { DH L5/S1 } \\
\text { Tarlov Cysts } \\
\text { at S2 }\end{array}$ & L5/S1 & $\begin{array}{l}\text { AT L4/L5 } \\
\text { (Grade 4) } \\
\text { \& L5/S1 } \\
\text { (Grade 4) }\end{array}$ & None & None & 1 year & None & $\begin{array}{l}\text { Depression, } \\
\text { gastritis, } \\
\text { hysterectomy. }\end{array}$ \\
\hline$\# 846 \mathrm{~F}$ & $>5$ years & $\begin{array}{l}\text { Epidural, } \\
\text { MBB, } \\
\text { facet TRF }\end{array}$ & $\begin{array}{l}\text { Disc } \\
\text { osteophyte } \\
\text { L3/L4 } \\
\text { and post-op } \\
\text { changes }\end{array}$ & L3/L4 & $\begin{array}{l}\text { At L3/L4 } \\
\text { (Grade 4) }\end{array}$ & $\begin{array}{l}100 \% \text { x } 2 \\
\text { weeks }\end{array}$ & $\begin{array}{l}\text { Not } \\
\text { sustained }\end{array}$ & $\begin{array}{l}6 \\
\text { months }\end{array}$ & None & $\begin{array}{l}\text { Hysterectomy, } \\
\text { T10-L1 } \\
\text { anterior } \\
\text { fusion. }\end{array}$ \\
\hline
\end{tabular}

SI = Sacroilliac joint Injection, MBB = Lumbar Medial Branch/Dorsal Ramus Blocks from L3-L5, TRF = Lumbar Medial Branch/Dorsal Ramus Thermal Radiofrequency, VB = Vertrebroplasty, AT = Annular Tear, DE = Disc Extrusion, DB $=$ Disc Bulge, DH $=$ Disc Herniation NB : Grading of Annular Tear According to Modified Dallas Discogram Classification (10)

currently no clinical precedent for repeat treatment $(1,2)$. In addition, Peng and colleagues (9) also considered a time-limited response a clinical failure in their initial publication.

Differences in outcome for our patients with discogenic pain (i.e., positive provocation discography) could exist because of the small sample of patients in our cohort, the fact they were not kept supine for 24 hours postprocedure (which we did for practical rea- sons), and the presence of psychiatric comorbidity/medico-legal influences for some of our patients. While our treatment was not investigated in a controlled manner, the significant differences in outcomes should encourage closer inspection of methylene blue treatment for discogenic pain, in a nonresearch-based setting, where a complex interaction of factors are relevant to the pain experience.

Various treatments have previously been reported 
for discogenic pain with differing quality of studies and success rates. Intradiscal electrothermal therapy (IDET) has a reported clinical success rate (i.e., pain and function) in some uncontrolled cohort studies of between $75-79 \%$ of patients, with improved success correlated with discographic concordance, high intensity zones, Pfirrmann grade, and the percentage of annulus coverage $(3,4)$. Pauza et al $(5)$ reported on a blinded randomized controlled trial (RCT) showing an improvement in function for treated patients and that $40 \%$ of treated patients achieved at least $50 \%$ pain relief, while $33 \%$ of patients in the placebo group achieved the same. Other studies, including one larger case series (6) and a blinded, randomized placebo control trial (7) showed little to no benefit at follow-up.

Intradiscal steroids may be beneficial for patients with end plate change and disc pain, but when not controlling for Modic changes, 2 RCTs showed no differences compared to placebo. $(6,8-9)$. In case series reports, intraforaminal and/or intradiscal ozone treatment has a reported success rate of $55-90 \%$ depending on the study, previous surgical spine procedure, and the type and number of disc herniations $(10,11)$ Intradiscal biacuplasty has been shown effective in small case series, but no controlled trials have been published $(12,13)$. Intradiscal radiofrequency thermo-coagulation has been shown ineffective in 2 RCTs $(14,15)$. The value of rami communicans radiofrequency thermo-coagulation remains to be seen. Despite its efficacy, the use of the enzyme chymopapain has been stopped due to complications, supply, and dosing issues (6). Finally, lumbar transpedicular fusion is not more beneficial at longterm follow-up than exercise and cognitive intervention in patients with nonspecific low back pain and disc degeneration as seen on magnetic resonance imaging (16).

Based on our results and review of the literature, discogenic low back pain continues to be an elusive, difficult-to-treat entity. We have reserved further treatment with methylene blue until further studies can elucidate more clearly which patients, if any, can reliably benefit.

\section{Acknowledgments}

The authors gratefully acknowledge the unrestricted funding support provided for Dr. Gaurav Gupta's fellowship training by the Louise and Alan Edwards Foundation and Pfizer Canada.

\section{References}

1. Papageorgiou AC, Croft PR, Ferry S, Jayson MI, Silman AJ. Estimating the prevalence of low back pain in the general population. Evidence from the South Manchester Back Pain Survey. Spine (Phila Pa 1976) 1995; 20:1889-1894

2. Raspe $\mathrm{HH}$, Kohlmann T. The current backache epidemic. TherUmsch 1994; 51:367-374.

3. Becker A, Held H, Redaelli M, Chenot JF, Leonhardt C, Keller S, Baum E, Pfingsten M, Hildebrandt J, Basler HD, Kochen MM, Donner-Banzhoff N, Strauch K. Implementation of a guideline for low back pain management in primary care: A cost-effectiveness analysis. Spine(Phila $\mathrm{Pa}$ 1976) 2012 Apr 15;37(8):701-710

4. Von Korff M. Studying the natural history of back pain. Spine (Phila Pa 1976)1994; 19:2041S-2046S.

5. DePalma, MJ, Ketchum, JM, Saullo, T. What is the source of chronic low back pain and does age play a role? Pain Med 2011; 12:224-233.
6. Kallewaard JW, Terheggen MA, Groen GJ, Sluijter ME, Derby R, Kapural L, Mekhail N, van Kleef M. 15. Discogenic low back pain. Pain Pract 2010; 10:560-579.

7. Bogduk N. A cure for back pain? Pain 2010; 149:7-8.

8. Peng $B$, Pang $X, W u Y$, Zhao $C$, Song, Xinghua. A randomized placebo-controlled trial of intradiscal methylene blue injection for the treatment of chronic discogenic low back pain. Pain 2010; 149:124-129.

9. Peng B, Zhang Y, Hou S, Wu W, Fu X. Intradiscal methylene blue injection for the treatment of chronic discogenic low back pain. Eur Spine ] 2007; 16:33-38.

10. International Spine Intervention Society. Practice Guidelines for Spinal Diagnostics and Treatment Procedures. Library of Congress Cataloging in Publication Data 2004:23.

11. U.S Food and Drug Admnistration. FDA Drug Safety Communication: Serious CNS reactions possible when meth- ylene blue is given to patients taking certain psychiatric medications. July 26, 2011. Available at www.fda. gov/Drugs/DrugSafety/ucm263190. htm?utm_campaign=Google2\&utm _ source $=f d$ a S e a r ch \&ut m m ediu m $=$ we bsite $\&$ ut m term=methylene\%2oblue\&utm_content=1, Accessed May 3, 2012.

12. Ghahreman A, Ferch R, Bogduk N. The efficacy of transforaminal injection of steroids for the treatment of lumbar radicular pain. Pain Med 2010; 11:11491168.

13. Rambaransingh B, Stanford G, Burnham $R$. The effect of repeated zygapophysial joint radiofrequency neurotomy on pain, disability, and improvement duration. Pain Med 2010; 11:1343-1347.

14. Assietti R, Morosi M, Migliaccio G, Meani L, Block JE. Treatment of discogenic low back pain with intradiscal electrothermal therapy (IDET): 24 months follow-up in 50 consecutive patients. Acta Neurochir Suppl 2011; 108:103-105. 
15. Maurer P, Block JE, Squillante D. Intradiscal electrothermal therapy (IDET) provides effective symptom relief in patients with discogenic low back pain. J Spinal Disord Tech 2008; 21:55-62.

16. Pauza KJ, Howell S, Dreyfuss P, Peloza JH, Dawson K, Bogduk N. A randomized, placebo-controlled trial of intradiscal electrothermal therapy for the treatment of discogenic low back pain. Spine J 2004; 4:27-35.

17. Freedman BA, Cohen SP, Kuklo TR, Lehman RA, Larkin P, Giuliani JR. Intradiscal electrothermal therapy (IDET) for chronic low back pain in active-duty soldiers: 2-year follow-up. Spine J 2003; 3:502-509.

18. Freeman BJ, Fraser RD, Cain CM, Hall
DJ, Chapple DC. A randomized, double-blind, controlled trial: Intradiscal electrothermal therapy versus placebo for the treatment of chronic discogenic low back pain. Spine (Phila Pa 1976) 2005; 30:2369-2377.

19. Buttermann GR. The effect of spinal steroid injections for degenerative disc disease. Spine J 2004; 4:495-505.

20. Simmons JW, McMillin JN, Emery SF, Kimmich SJ. Intradiscal steroids. A prospective double-blind clinical trial. Spine (Phila Pa 1976) 1992; 17:S172-S175.

21. Muto M, Ambrosanio G, Guarnieri G, Capobianco E, Piccolo G, Annunziata G, Rotondo A. Low back pain and sciatica: Treatment with intradiscal-intraforami- nal O(2)-O (3) injection. Our experience. Radiol Med 2008; 113:695-706.

22. Buric J, Molino Lova R. Ozone chemonucleolysis in non-contained lumbar disc herniations: A pilot study with 12 months follow-up. Acta Neurochir Suppl 2005; 92:93-97.

23. Karaman H, Tüfek A, Kavak GÖ, Kaya $S$, Yildirim ZB, Uysal E, Celik F. 6-month results of transdiscal biacuplasty on patients with discogenic low back pain: Preliminary findings. Int ] Med Sci 2010; 8:1-8.

24. Kapural L, Sakic K, Boutwell K. Intradiscal biacuplasty (IDB) for the treatment of thoracic discogenic pain. Clin J Pain 2010; 26:354-357. 